\title{
FILSAFAT MANUSIA
}

"Pemasungan Yang Kian Marak di Indonesia Hingga Pemerintah Turun Tangan Untuk Membantu Mengatasi Kasus Pemasungan Yang Terjadi Ditinjau Dari Sudut Pandang Intelek dan Kehendak Manusia"

Paper Mata Kuliah Filsafat Manusia

Dosen Pengampu : Dr. Agustinus W. Dewantara, S.S., M. Hum

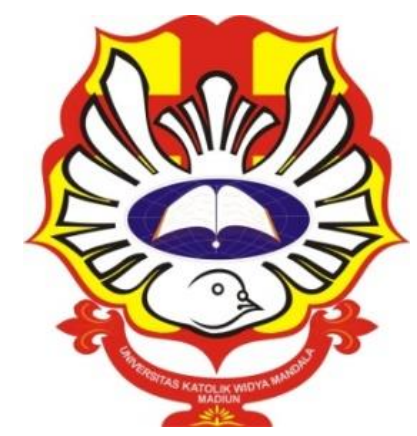

Disusun oleh :

Nama : Ezra Agdanius

NIM : 41417006

PROGRAM STUDI TEKNIK INDUSTRI

FAKULTAS TEKNIK

UNIVERSITAS KATOLIK WIDYA MANDALA SURABAYA

KAMPUS MADIUN 


\title{
Pemasungan Yang Kian Marak di Indonesia Hingga Pemerintah Turun Tangan Untuk Membantu Mengatasi Kasus Pemasungan Yang Terjadi Ditinjau Dari Sudut Pandang Intelek dan Kehendak Manusia
}

Oleh :

\author{
Ezra Agdanius Kharisma Hutagalung \\ Universitas Katolik Widya Mandala Surabaya Kampus Madiun
}

\begin{abstract}
ABSTRAC
Kasus pemasungan pada saat ini kian marak di Indonesia. Kasus pasung dapat dikatakan sebagai tindakan yang tidak manusiawi dan dapat menurunkan martabat dan mengurangi kualitas hidup orang dengan mental sakit. Pada dasarnya, tindakan pasung ini diakibatkan oleh gangguan jiwa yang tidak tertatalaksana dengan baik dan dapat mengakibatkan gejala semakin sulit untuk diatasi, gangguan menahun, dengan penurunan fungsi sosial dan okupansial yang semakin berat. Perlu disadari juga tindakan pemasungan merupakan sifat pelanggaran terhadap Hak Asasi Manusia pada kelompok rentan dengan faktor resiko yang sebenarnya dapat diturunkan resikonya sehingga tidak perlu mengakibatkan dampak dan beban yang besar terutama bagi ODGJ dan keluarganya. Seperti apa yang dikatakan Carl Gustav Jung, manusia memiliki kebebasan dalam hal apapun, kebebasan tersebut tetap ada dalam aturan baik secara spiritualistic maupun materialistic. Diperlukan beberapa pihak baik keluarga maupun pemerintah untuk mengurangi kasus pemasungan yang terjadi di Indonesia.
\end{abstract}

KEYWORDS : Pemasungan, Gangguan Jiwa, Pemerintah

\section{Pendahuluan}

Pemasungan pada orang dengan gangguan jiwa ( ODGJ ) merupakan pelanggaran Hak Asasi Manusia berat karena dilakukan pada orang dengan disabilitas yang mengakibatkan tidak mampu mengakses layanan yang dapat mengurangi tingkat disabilitasnya. Tindakan pemasungan merupakan tindakan pengekangan, pembatasan aktivitas secara fisik, menggunakan berbagai jenis alat seperti rantai, belenggu, tali, balok, kayu, kurungan, diasingkan, atau dirantai pada ruangan terasing. Tindakan pasung dilakukan pada pasien gangguan jiwa kronik, disertai perilaku yang sangat agresif, kekerasan, mengamuk, yang beresiko menciderai diri sendiri, orang lain, maupun lingkungan. Upaya bebas pasung merupakan program prioritas yang harus dicapai Pemerintah di tahun 2019 ini. Saat ini upaya bebas pasung telah terlaksana dengan baik. 
Keluarga yang mempunyai klien gangguan jiwa yang dipasung seringkali merasakan beban yang berkaitan dengan klien. Alasan keluarga melakukan pemasungan adalah mencegah perilaku kekerasan, mencegah resiko bunuh diri, mencegah klien meninggalkan rumah dan ketidakmampuan merawat klien gangguan jiwa. Dukungan keluarga untuk klien adalah sikap, tindakan dan penerimaan keluarga terhadap penderita yang sakit.

Pemasungan terhadap orang dengan masalah kejiwaan dan orang gangguan jiwa bertentangan dengan Undang-Undang Dasar Negara Republik Indonesia Tahun 1945 melindungi hak semua orang termasuk orang dengan masalah kejiwaan dan orang dengan gangguan jiwa. Kemudian, pengaturan dalam Pasal 42 Undang-Undang Nomor 39 Tahun 1999 tentang Hak Asasi Manusia menyatakan : “ Setiap warga negara yang berusia lanjut, cacat fisik dan atau cacat mental berhak memperoleh perawatan, pendidikan, pelatihan, dan bantuan khusus atas biaya negara, untuk menjamin kehidupan yang layak sesuai dengan martabat kemanusiaannya, meningkatkan rasa percaya diri, dan kemampuan berpastisipasi dalam kehidupan bermasyarakat, berbangsa, dan bernegara.

Seperti kasus yang berada di Kab Banyumas, Jawa Tengah dimana terdapat seorang pemuda yang dipasung oleh pihak keluarganya. Dimana pemuda ini mengalami gangguan jiwa sejak tahun 2006 semenjak ia pulang dari Ibu Kota, mengikuti bapaknya yang jadi kuli bangunan disana. Oleh pihak keluarganya, pemuda tersebut dikurung disebuah ruangan yang berukur 1,5m x 1,5m. Pemuda tersebut dikurung oleh pihak keluarganya lantaran sering keluar kemanapun dan juga sering mengamuk, akibatnya ia dipasung agar tidak meresahkan warga sekitar didesanya. Selain itu pihak keluarga sudah melakukan pengobatan terhadap pemuda ini, sampai dibawa ke Banyumas, namun butuh waktu yang sangat lama dan juga biaya banyak pihak keluarga terpaksa memberhentikan pengobatan pemuda ini lantaran tidak cukup biaya untuk melakukan pengobatan atau perawatan terhadap pemuda ini.

Berdasarkan kasus yang dijelaskan diatas, penulis ingin menyoroti maraknya pemasungan terhadap orang yang mengalami gangguan kejiwaan di negara ini dengan menggunakan aliran indeterminisme dan sintese, sesuai pendapat Fichte yaitu manusia menentukan itu bebas mutlak, bahkan semua hal terjadi secara kebetulan dan kehendak manusia memang dilakukan secara bebas. Harapan dari penulis ini adalah untuk menyadari dimana manusia mempunyai Hak Asasi Manusia yang harus dipentingkan dan juga manusia hidup itu 
mempunyai aturan sebagai pedoman hidup, walaupun dewasa kini kita tengah hidup di era modern, kita harus peduli terhadap sesama kita yaitu sesama manusia.

\section{Hubungan Antara Kehendak dan Kebebasan}

Menurut Kamus Besar Bahasa Indonesia manusia adalah makhluk yang berakal budi, yang artinya manusia adalah makhluk yang paling istimewa dibanding makhluk lain. Manusia adalah makhluk sosial karena membutuhkan orang lain untuk berinteraksi dan kelangsungan hidupnya. Didalam kehidupan kita sebagai manusia tentu diatur didalam Undang-Undang yang di negara kita ini yang tujuannya ialah sebagai pedoman yang baik.

Berdasarkan ketentuan Pasal 42 tersebut orang dengan masalah kejiwaan dan orang dengan gangguan jiwa dianggap sebagai cacat mental maka mereka berhak memperoleh perawatan,

pendidikan pelatihan dan juga bantuan khusus dari negara, sehingga tidak seharusnya orang dengan masalah kejiwaan dan orang dengan gangguan jiwa harus mengalami pemasungan. Selanjutnya, didalam Pasal 148 Ayat (1) Undang-Undang Nomor 36 Tahun 2009 mengatakan bahwa "Penderita gangguan jiwa mempunyai hak yang sama sebagai warga negara ". Tetapi pada saat ini pasal itu tidak lagi berfungsi dikarenakan banyak tindakan penindasan kepada orang yang mengalami gangguan jiwa seperti contoh yang penulis saat ini ambil yaitu kasus pemasungan.

Undang-undang yang dibuat untuk menuju ketentraman didalam menjalani kehidupan sehari-hari, namun pada dasarnya karena perbedaan manusia satu dengan manusia lainnya. Cara berpikir manusia berbeda-beda dan beraneka ragam untuk menjadikan upaya bagi setiap individunya untuk mencari keberadaan bahwa hidup manusia yang terdapat aturan untuk membuat dan menjadikan manusia yang beradab.

Seperti pendapat Carl Gustav Jung mengenai kepribadian secara garis besar membahas tentang tingkah laku manusia yang ditentukan berdasarkan kasualitas dan tujuan-tujuan tertentu. Kepribadian tersebut dipengaruhi oleh masa lalu, tetapi juga berpandangan kepada masa depan. Struktur kepribadian tersebut terdiri atas kesadaran, ketidaksadaran pribadi, ketidaksadaran kolektif dan lain sebagainya. Teori yang ditekankan oleh Carl Gustav Jung dipandang sebagai teori psikoanalitik yang mengarah kepada kepribadian manusia.

Manusia memiliki kebebasan dalam melakukan hal apapun, suatu keputusan untuk melakukan hal kebebasan yang didasarkan bahwa manusia harus tunduk pada apa yang telah diputuskan untuk mengetahui bahwa batasan untuk kebebasan tersebut ada ukurannya. Hal ini 
didasarkan bahwa manusia sendiri tidak bebas. Didapat dari sudut pandang secara spritiualistik dijelaskan bahwa kebebasan manusia ternyata diarahkan pada hal yang baik, meskipun pada nyatanya arah kebebasan tidak terarah tetapi tetap ada batasannya.

\section{Hubungan Antara Keluarga, Pemerintah Dalam Kasus Pemasungan}

Ulasan ini akan membahas mengenai pemasungan yang terjadi di Negara Indonesia kini. Maraknya kasus pemasungan ini membuat pemerintah sedang tidak baik-baik saja. Hal ini membuat dewasa ini sedih sekaligus miris melihat pemuda yang dipasung terjadi di Kota Banyumas, Jawa Tengah. Bagaimana tidak, pasalnya pihak keluarga memasung pemuda tersebut di ruangan yang berukuran $1,5 \mathrm{~m}$ x 1,5m. Didalam berita tersebut pemuda ini hanya sedang duduk didalam ruangan miliknya tersebut dengan kondisi kumal tidak terawatt.

Ketika batasan ini memudar akan timbul masalah yang seperti ini, hilangnya rasa peduli, hilangnya rasa kasih sayang dan juga hilangnya rasa memanusiakan manusia. Seharusya di era modern seperti ini pemasungan menjadi hal yang sangat minim, karena pemerintah sudah menyiapkan fasilitas-fasilitas untuk berobat. Didalam era seperti ini peran kita sangatlah penting untuk mengurangi pemasungan yang kerap kali terjadi.

Kasus pemasungan ini terjadi karena pihak keluarga merasa tidak punya keuangan yang lebih untuk membawa pasien ke rumah sakit, dan kurangnya sosialisasi dari pemerintah ke masyarakat setempat. Didalam kehidupan sehari-hari, mungkin dari pihak keluarga merasa lebih nyaman dan tenang kepada korban karena sudah dipasung. Tetapi pada sudut pandang dunia kesehatan ini sangatlah buruk, karena akan menambah beban kepada korban.

Melihat, kasus ini dilihat dari 2 sudut pandang antara korban pemasungan dengan pihak keluarga yang memasung. Alasan keluarga yang memasung dikarenakan sudah tidak punya biaya lagi untuk memberi pengobatan dan juga korban mempunyai beban yang semakin bertambah. Walaupun secara undang-undang orang dalam gangguan jiwa berhak mendapat kebebasan, kebebasan yang dimaksud adalah diberikan ruang lingkup yaitu mungkin dengan dimasukkan didalam Rumah Sakit Jiwa.

Peran keluarga sangatlah penting didalam kasus pemasungan ini, dimana keluarga adalah inti utama untuk pasien menjadi sembuh. Dengan melakukan perawatan seperti, memberi makan dan minum. Keluarga adalah sumber bantuan yang paling praktis untuk pasien dalam pemenuhan kebutuhan sehari-hari. Keluarga harus benar-benar memperhatikan keadaan pasien tersebut, jangan merasa bodo amat terhadap pasien yaitu keluarganya sendiri. 
Selain peran keluarga, peran Pemerintah sangatlah penting untuk menangani kasus pemasungan, dari kasus ini dimana Pemerintah Provinsi Jawa Tengah turun tangan langsung menghampiri serta membawa pemuda ini ke Rumah Sakit Jiwa dan dari pihak keluarga pun setuju. Penulis merasa senang dengan Pemerintah setempat turun langsung untuk mengeksekusi ini menandakan Pemerintah peduli terhadap warganya. Ini seharusnya membuat motivasi pemerintah manapun untuk turun langsung kepada masyarakatnya dan melihat masyarakatnya. Karena selain dari pihak keluarga pemerintah juga sangat penting untuk menangani kasus pemasungan yang kerap terjadi di negara Indonesia ini, mungkin fasilitas-fasilitas dan juga jaminan dari Pemerintah ini membuat keluarga dan juga korban merasa nyaman. Selain itu Pemerintah bisa menerapkan sosialisasi kepada warganya tentang larangan untuk pemasungan, banyak dari warga-warga khususnya yang tempatnya jauh dari pusat kota jauh dari kata-kata modern. Maka dari itu, sosialisasi dari pemerintah akan mendapat respon yang sangat baik dari masyarakat. Sosialisasi tersebut isinya mungkin tentang kesehatan, larangan undang-undang untuk korban yang dipasung,

Selain dari pemerintah, masyarakat sekitar sangat penting juga untuk modal kesehatan korban pemasungan. Masyarakat sekitar harus mempunyai sikap peduli kepada keluarga korban atau korban pemasungan. Peduli ialah mungkin secara memberikan semangat kepada keluarga korban dan juga korban baik secara materi maupun non materi.

Dari kasus yang penulis ambil dari pihak keluarga tidak mempunyai biaya untuk melanjutkan pengobatan anaknya, alhasil keluarga mempunyai tekad untuk memasung anaknya. Dari pihak keluarga mempunyai pendapat bahwa dengan dipasung akan membuat beban keluarga berkurang dan pasien mungkin akan bertambah baik. Namun, dilihat dari kacamata dunia bahwa pemasungan membuat pasien/korban akan bertambah buruk. Dari Pemerintah setempat juga turun langsung untuk menangani kasus pemasungan, hal ini menjadi dampak positif bagi kita semua yang peduli pada sesama manusia. Lantaran pemerintah ikut membantu korban pemasungan dengan diberikannya fasilitas dan jaminan. Korban pemasungan disini tidak menggunakan metode dirantai melainkan menggunakan metode kurung. Aktivitas yang dilakukan dari mulai buang air kecil (BAK) dan juga buang air besar (BAB) dilakukan ditempat tersebut, dari segi kesehatan ini berdampak buruk bagi kesehatan pasien.

\section{Saran dan Kesimpulan}


Melihat kasus pemasungan yang terjadi di Negara Indonesia ini pemerintah sedang tidak dikatakan baik-baik saja. Pasalnya banyak wilayah di Indonesia ini terjadi kasus pemasungan, sebenarnya hal ini dapat dikurangi apabila pemerintah memperhatikan kasus pemasungan yang marak terjadi. Bukan hanya dari pemerintah saja yang dapat menanggulangi kasus pemasungan ini, tetapi juga kita yang disebut manusia dapat membantu mengurangi kasus pemasungan ini. Solusi untuk pemerintah agar lebih memperhatikan kasus pemasungan ini bahkan turun tangan langsung membantu kasus pemasungan. Contohnya dengan memberikan layanan kesehatan dan fasilitas-fasilitas untuk korban pemasungan, selain itu pemerintah harus membuat program kerja sosialisasi di berbagai tempat agar tujuannya masyarakat terpencil maupun tidak mengerti bahwa pemasungan itu dilarang oleh negara karena melanggar hak asasi manusia. Solusi untuk pihak keluarga untuk mampu mencari jalan keluar selain pemasungan, dengan cara mungkin datang ke kantor pemerintah pihak setempat dan berdiskusi. Untuk masyarakat setempat yang tinggal didaerah terdapat pemasungan mungkin dapat membantu mensosialisasikan atau bahkan lebih peduli terhadap keluarga dan korban pemasungan. Kita adalah manusia, seharusnya kita mampu untuk lebih memanusiakan manusia. Meskipun itu sulit untuk dijalani apa salahnya untuk mencoba. Harapan dari penulis semoga kasus pemasungan ini berkurang dari tahun ke tahun, apabila pemerintah pihak setempat sudah melakukan perhatian terhadap warga-warganya yang mengalami pemasungan harap lebih ditingkatkan kembali dan bagi pemerintah yang belum melaksanakan harap ini menjadi perhatian yang lebih. Dan untuk semuanya mari kita mencoba melihat sekitar kita adakah yang menderita pemasungan, bila ada mari kita bantu dengan cara mendatangi pemerintah setempat dan juga berdiskusi kepada keluarga tentang larangan pemasungan. Mari kita sama-sama lebih peduli dan memanusiakan manusia. 


\section{DAFTAR PUSTAKA}

Dewantara, A. (2017). Filsafat Moral (Pergumulan Etis Keseharian Hidup Manusia). Sumber :

Youtube : https://youtu.be/VvyzVJDblQe “ Merayu” Pemuda yang Mengalami Gangguan Jiwa 